\title{
Pain Treatment in Arthritis-Related Pain: Beyond NSAIDs
}

\author{
Mart van de Laar ${ }^{*}$, , Joseph V. Pergolizzi Jr. ${ }^{2}$, Hans-Ulrich Mellinghoff ${ }^{3}$, Ignacio Morón Merchante ${ }^{4}$, \\ Srinivas Nalamachu ${ }^{5}$, Joanne O'Brien ${ }^{6}$, Serge Perrot ${ }^{7}$ and Robert B. Raffa ${ }^{8}$ \\ ${ }^{1}$ Arthritis Center Twente (MST \& UT), Enschede, The Netherlands \\ ${ }^{2}$ Johns Hopkins University, Baltimore, Maryland, USA; Association of Chronic Pain Patients, Houston, Texas, USA \\ ${ }^{3}$ Department of Endocrinology, Diabetology and Osteology, Kantonsspital St. Gallen, Switzerland \\ ${ }^{4}$ Centro de Salud Universitario Goya, Madrid, Spain \\ ${ }^{5}$ Kansas University Medical Center, Kansas City, Kansas, USA and International Clinic Research, Leawood, Kansas, \\ USA \\ ${ }^{6}$ Department of Pain Management, Beaumont Hospital, Beaumont, Dublin, Ireland \\ ${ }^{7}$ Service de Médecine Interne et Consultation de la Douleur, Hôpital Dieu, Paris, France \\ ${ }^{8}$ Department of Pharmaceutical Sciences, Temple University School of Pharmacy, Philadelphia PA, USA
}

\begin{abstract}
Managing pain from chronic conditions, such as, but not limited to, osteoarthritis and rheumatoid arthritis, requires the clinician to balance the need for effective analgesia against safety risks associated with analgesic agents. Osteoarthritis and rheumatoid arthritis pain is incompletely understood but involves both nociceptive and non-nociceptive mechanisms, including neuropathic mechanisms. Prevailing guidelines for arthritis-related pain do not differentiate between nociceptive and non-nociceptive pain, sometimes leading to recommendations that do not fully address the nature of pain. NSAIDs are effective in treating the nociceptive arthritis-related pain. However, safety concerns of NSAIDs may cause clinicians to undertreat arthritis-related pain. In this context, combination therapy may be more appropriate to manage the different pain mechanisms involved. A panel convened in November 2010 found that among the currently recommended analgesic products for arthritis-related pain, fixed-low-dose combination products hold promise for pain control because such products allow lower doses of individual agents resulting in decreased toxicity and acceptable efficacy due to synergy between the individual drugs. Better evidence and recommendations are required to improve treatment of chronic arthritis-related pain.
\end{abstract}

Keywords: Osteoarthritis, rheumatoid arthritis, analgesia, fixed-dose combination products, NSAID, paracetamol, tramadol.

\section{INTRODUCTION}

Osteoarthritis (OA) and rheumatoid arthritis (RA) cause chronic pain, which may involve nociceptive as well as nonnociceptive components, including neuropathic components, due to peripheral inflammation and central sensitization [1, 2]. Despite our modern wealth of analgesic options, managing moderate to severe chronic pain remains clinically challenging for several reasons. These reasons include: the heterogeneity of the patient populations, the progressive nature of the disorders, the multiple pain mechanisms involved, the presence of comorbidities and co-medication in predominantly frail and elderly patients, and the efficacy and safety profiles of available pain medications [3]. OA and RA patients frequently require lifelong pain management regimens, ruling out those pharmacological therapies effective for acute pain but inappropriate for long-term use.

*Address correspondence to this author at the Reumacentrum Twente (MST \& UT), postbus 50.000, 7500KA ENSCHEDE, The Netherlands; Tel: +31-

53-4872450; Fax: +31-53-4873106; E-mail: M.vandeLaar@mst.nl
In fact, many analgesic agents carry a substantial degree of risk, which has created barriers in pain management, in that clinicians may undertreat pain in an effort to enhance patient safety and minimize potential side effects [4]. Since chronic pain itself is associated with considerable mortality [5-7], public health organizations today view effective analgesia as a fundamental human right [8-10]. Not treating pain is not an option.

\section{ISSUES IN OA PAIN}

$\mathrm{OA}$ is a prevalent disorder characterized by the progressive destruction of articular cartilage associated with subchondral bone remodeling, formation of osteophytes, and secondary inflammation of synovial membranes $[11,12]$. Its principal symptom is pain, which is mediated by a number of factors. Amongst others, innervation and vascularisation of the articular cartilage may be involved, and compressive forces and hypoxia may stimulate these new nerves, causing pain even after inflammation has subsided [13]. Innervation of the joint tissue and angiogenesis have been described as main pathophysiological pathways causing the deep joint 
pain described by some OA patients [13, 14]. The pain of OA includes both nociceptive and non-nociceptive components and is associated with abnormally excitable pain pathways in the peripheral and central nervous systems [15, 16]. Quantitative sensory testing in OA patients reveals that OA patients have lower thresholds for mechanical and thermal pain than healthy controls $[1,17]$ and increased sensitivity to pressure, ischemia, and innocuous stimuli [18]. OA patients were shown to have lower pain thresholds than control subjects at the forehead, a non-painful area of the body unaffected by OA [19]. Such findings suggest that OA pain is also centrally mediated [20]. Functional magnetic resonance imaging (fMRI) studies have identified several brain regions involved in OA pain processing, indicating the complexity of OA pain mechanisms [21].

$\mathrm{OA}$ is prevalent in the global geriatric population [22]. In general, long-term analgesia is challenging in the elderly, a challenge not always addressed in the literature or guidelines. Since few randomized clinical trials enroll geriatric patients, and even fewer enroll elderly patients of diverse races and ethnicities, there are limited data available in the literature for this particular population. Furthermore, elderly patients often have comorbidities, which may increase the risk of drug-drug interactions and limit the range of drugs to be used. Age-associated differences in drug sensitivities should be considered when treating older patients [23], although the heterogeneous nature of the geriatric OA population precludes clear-cut uniform guidelines for all elderly OA patients. Opioids have been shown to be effective in the elderly, but must be used under close clinical supervision [24].

\section{ISSUES IN RA PAIN}

RA is a progressive disorder characterized by periods when the disease is active punctuated by periods of remission. Patients may suffer persistent or intermittent pain, which can be moderate to severe. RA is an inflammatory disease that causes destruction of cartilage and underlying bone. Since the joint capsule and synovium are densely innervated, pain can be intense and may be triggered by even gentle stimulation or slight movement of the affected joint [25]. The local inflammatory response is mediated by the immune system along with resident non-immune cells (synovial fibroblasts). Local inflammation triggers the release of multiple factors, including pro-inflammatory cytokines, histamines, bradykinins, serotonin, prostaglandin E2, and others. Peripheral nociceptors become sensitized owing to the altered cytokine balance. Cellular cascades initiate central sensitization [25]. RA patients have lower thresholds for pressure pain than healthy controls, further suggesting altered central pain processing [26, 27]. Enhanced cortical responses to noxious stimuli in RA patients suggest cellular changes affecting pain-processing signals [28]. Peripheral sensitization, central sensitization, and inflammation interact in RA patients in ways not yet completely understood.

\section{MEETING DETAILS}

In November 2010, a panel convened in Paris, France, to discuss the management of moderate to severe pain from different etiologies with special emphasis on NSAIDs, paracetamol and fixed-dose combination products. Following presentations by several authors of this article, all authors discussed and reviewed pain management and available guidelines/recommendations based on their own clinical experiences. Their final consensus on pain management for the indications osteoarthritis and rheumatoid arthritis is summarized in this publication and incorporates additional articles which were deemed relevant in discussions during the draft stages.

\section{CURRENT ANALGESICS USED TO TREAT ARTHRITIS-RELATED PAIN}

The focus of rheumatology is the best possible patient care and management of disease-related pain and impact on the patient by understanding the underlying pathophysiological aspects of this inflammatory disease process. Greater understanding of pain mechanisms and growing appreciation for pain control have, however, caused rheumatologists to consider new approaches in pain management. Whereas central pain mechanisms are increasingly addressed in the pharmacological therapy for fibromyalgia patients, it is less clear how to manage the centralized pain processes in OA and RA patient populations. Therefore, it has been proposed that clinicians change the concept of pain control in arthritis-related pain to one of "pain-modifying analgesic drugs" [29]. The following drugs are the main categories of pharmacological agents used for pain control in OA and RA patients. It should be noted that all treatment options may be combined with nonpharmacological approaches.

\section{Nonsteroidal Anti-Inflammatory Drugs (NSAIDs)}

Both selective and nonselective cyclooxygenase (COX) inhibitors have antipyretic, anti-inflammatory and analgesic effects and are widely used in treating many painful conditions, including rheumatic diseases [30]. NSAIDs are effective and widely available in over-the-counter formulations and in prescription products. Examples include ibuprofen, naproxen, diclofenac, and celecoxib. NSAIDs are frequently used without considering the relative contraindications since most NSAIDs are sold over the counter [31]. Conventional NSAIDs are associated with gastrointestinal (GI) side effects [32]. Estimates of the number of deaths from NSAID-related gastrointestinal bleeding vary widely and figures of approx. 3500 to 16.500 per year are quoted for the US in a recent FDA report [33]. Both conventional NSAIDs and COX-2 inhibitors are associated with increased cardiovascular risk [34-37]. NSAIDs may increase blood pressure [38], particularly in hypertensive patients [39]. Of all NSAIDs, naproxen seems to pose the least cardiovascular risk [37, 40], although naproxen is associated with the same risk for myocardial infarction as other NSAIDs [35].

Contrary to some clinical assumptions, gastrointestinal risk is present at first dose with a non-selective NSAID, and co-therapy with a proton pump inhibitor (PPI) does not guarantee complete protection [41]. COX-2 selective NSAIDs, especially in combination with a PPI, provide prophylaxis against NSAID gastropathy [42]. The incidence 
and severity of gastrointestinal adverse events associated with NSAID therapy increases with advancing age, limiting their clinical utility in the geriatric population, particularly in concomitant use with low-dose aspirin, taken by many elderly patients for cardioprotection [43, 44]. NSAIDs should be used at the lowest effective dose for the shortest possible period of time in chronic pain populations. In addition to the above mentioned risks, NSAIDS may interact with many other medicinal products [45-48] and special caution and close monitoring is recommended in particular for elderly patients and patients with a history or symptoms indicative of gastrointestinal disorders, patients with renal, cardiac or hepatic impairment, a history of hypertension, asthma, seasonal allergic rhinitis, systemic lupus erythematosus (SLE) and mixed connective tissue disorders [45-48]. Very rarely serious skin reactions, some of them fatal, including exfoliative dermatitis, Stevens-Johnson syndrome and toxic epidermal necrolysis, have been reported in association with the use of NSAIDs [45-48]. Accumulated toxicity and the above-mentioned potential risks are the main reasons that there are no suitable agents for long-term treatment $[49,50]$.

\section{Paracetamol}

The antipyretic and analgesic effects of paracetamol (acetaminophen or APAP) have been known since the late 19th century. It is often considered a first-line approach to pain management [51], although there is a risk of hepatoxicity at high doses. Even at recommended therapeutic doses of paracetamol up to $4 \mathrm{~g} / \mathrm{d}$, otherwise healthy adults can exhibit abnormally high levels of aminotransferase [52]. Although high doses of paracetamol are known to be toxic, such supratherapeutic doses of paracetamol are sometimes prescribed and dispensed [53]. Paracetamol is widely available over the counter and in prescription products and many combination products contain paracetamol, but patients may equate the drug's familiarity with safety and wrongly consider it more or less harmless. Twelve percent of patients believe that it is not possible to ingest a toxic dose of paracetamol [54]. Furthermore, even patients who understand the potential toxicity of paracetamol may be unaware that it is found in a wide range of over-the-counter products from cold medicines to headache remedies. Patients taking such over-the-counter products may be unaware of "hidden paracetamol" in such products and unaware of the risk of high cumulative doses [54].

Paracetamol was shown in one study to significantly increase blood pressure in ambulatory patients with coronary artery disease [55]. The frequency of use of paracetamol has been independently associated with a moderately increased risk of hypertension in men [56]. There is some evidence in the literature to suggest that paracetamol may have an antiinflammatory effect in patients with OA of the knee [57]. Although earlier reports describe paracetamol as having no or minimal anti-inflammatory effects, increasing reports suggest, that in addition, it may have a beneficial effect on inflammation distinct from the anti-inflammatory effects of NSAIDs [58]. Further study in that field is warranted.

\section{Tramadol}

Tramadol is considered a weak opioid on the WHO pain ladder [59]. Due to its differences to other opioids, it will be discussed separately here. Tramadol's analgesic effect derives from a combination of an agonist action at mu-opioid receptors (low affinity of parent drug, much higher affinity of its M1, O-desmethyl, metabolite) and inhibition of neuronal reuptake of serotonin (5-HT, 5-hydroxytryptamine) and norepinephrine [60]. Tramadol has been shown to decrease pain intensity in OA patients and to improve function; active-controlled studies show that tramadol provides analgesic benefits similar to diclofenac and superior to paracetamol [61]. Extended-release formulations of tramadol have been shown effective in treating chronic pain associated with OA as well as offering improvement in painrelated sleep disorders [62].

Tramadol may be associated with a risk of dependence or abuse; the prevalence of abuse/dependence over a 12-month period in patients with chronic non-cancer pain was, however, equivalent for tramadol and NSAIDs, and significantly less than for hydrocodone [63]. In patients prone to convulsive disorders, the risk of convulsions may increase if tramadol is taken concomitantly with medication that lowers the seizure threshold. Some cases of serotonergic syndrome have been reported with the therapeutic use of tramadol in combination with other serotonergic agents such as selective serotonin re-uptake inhibitors (SSRIs) [64]. Recommended dosing should not exceed $400 \mathrm{mg} / \mathrm{d}$, and should be reduced or closely supervised in geriatric patients ( $\geq 75$ years) and those with cirrhosis or renal dysfunction [30]. Tramadol has no known anti-inflammatory effects.

\section{Opioids}

Since 1990, opioids have been recommended in the setting of long-term non-cancer pain syndromes [65]. Growing public health concerns about prescription opioid abuse and particularly about the diversion of prescribed products to the street have focused greater scrutiny on opioid prescribing practices [66-68]. Another concern regarding opioids is the perceived high danger of addiction. Various studies have, however, demonstrated that opioid analgesics for chronic pain conditions are not associated with a major risk for developing dependence [69]. Concern about opioid diversion and misuse has led to the development of so-called abuse-deterrent formulations, as a means for supporting opioid access while limiting abuse and its consequences $[70,71]$.

Opioids are effective in treating chronic pain [72] but are associated with side effects, including nausea, constipation, and somnolence. Opioids may be appropriate for use in the elderly under close supervision, sometimes at reduced doses [24], or as low-dose transdermal treatment, e.g., buprenorphine [73, 74]. Recently, tapentadol extendedrelease has shown promise in the treatment of moderate to severe chronic pain related to OA $[75,76]$.

In summary, clinicians may be cautious in prescribing opioids to treat OA or RA for clinical, legal, or public health reasons [77]. 


\section{Tricyclic Antidepressants}

Amongst other mechanisms, tricyclic antidepressants (TCAs, e.g. amitriptyline, dothiepin, and imipramine) inhibit serotonin and norepinephrine reuptake and neuronal sodium channels [78]. Various tricyclic TCAs differ with regard to their antinociceptive effects, and the non-serotoninergic properties of TCAs are believed to substantially contribute to these differences [79].

TCAs provide significant pain relief in RA patients versus placebo [80-83]. The use of TCAs in arthritis has found such a wide distribution that it has been proposed that these agents along with anticonvulsants should be described as "pain-modifying drugs" [29]. TCAs offer arthritis patients an analgesic benefit apart from their antidepressive effects. It has been speculated that at least part of this benefit relates to improvement of fatigue and sleep disorders [84]. TCAs are associated with certain adverse events, which include sedation, dizziness, blurred vision, constipation, and dry mouth, which can be treatment limiting. Dry mouth can be of particular concern for RA patients with secondary Sjögren's syndrome [20]. Cardiac toxicity is a concern with TCAs, and the NeuPSIG guidelines (Neuropathic Pain Special Interest Group) recommend prescribing TCAs with caution in patients with ischemic cardiac disease or ventricular conduction abnormalities [85]. Some TCAs, e.g. amitriptyline, are listed on the recently revised Beers list (American Geriatrics Society) of potentially inappropriate medication use in older adults with a strong recommendation to avoid using them because they are highly anticholinergic, sedating, and cause orthostatic hypotension [86]. Since arthritis primarily occurs in the elderly, TCAs are usually not suitable.

\section{Anticonvulsants}

Anticonvulsants, e.g., gabapentin and pregabalin, bind to the alpha2delta subunit of calcium channels and modulate the release of neurotransmitters, including glutamate, noradrenalin, serotonin, and substance P. As such, these agents may provide analgesic relief for patients with central sensitization. However, the mechanisms of action of these drugs are still poorly understood [87]. While known to be effective analgesics for fibromyalgia, these agents have not been studied in RA and OA populations. Pregabalin was shown in a preclinical study to be effective in reducing pain in an OA model [88]. Both agents are associated with adverse events. In a meta-analysis of pregabalin in adult acute and chronic pain patients, $18 \%$ to $28 \%$ of participants discontinued the study owing to adverse effects $(n=19$ studies with 7,003 patients) [89].

\section{Serotonin Norepinephrine Reuptake Inhibitors}

Serotonin norepinephrine reuptake inhibitors (SNRIs), inhibit serotonin and/or norepinephrine reuptake selectively, e.g., duloxetine and milnacipran. Overall, SNRIs are better tolerated than TCAs but may be less effective analgesics; they are not recommended as first-line drugs for analgesia in
RA patients, although they may be useful to manage sleeprelated symptoms [84]. A recent study found duloxetine was an effective analgesic in patients with OA of the knee [90].

\section{Corticosteroids}

Due to their potent anti-inflammatory effects, corticosteroids have been shown to be effective adjuvant analgesics in a variety of painful rheumatic conditions, including RA and other autoimmune disorders [91]. Concerns about especially long-term toxicity [92], and adverse events may reduce the clinical utility of these agents for long-term care [23]. According to the NICE guidelines for RA, patients with established RA should only continue long-term treatment with glucocorticoids when the long-term complications of glucocorticoid therapy have been fully discussed, and all other treatment options (including biological drugs) have been offered [49]. Long-term complications of glucocorticoid therapy include glucocorticoid-induced osteoporosis and risk of fracture [93], immunosuppression [94], elevated risk of infections, weight gain, thinning skin, muscle weakness, Cushing's syndrome, onset of diabetes or worsening of existing diabetes, hypertension, glaucoma, cataracts, and delayed wound healing [95].

\section{Topical Agents}

Topical products, such as lidocaine, diclofenac, capsaicin, and salicylate, allow the patient to obtain localized pain relief. They are mainly used in combination with systemic agents in the treatment of pain associated with rheumatic disease. Topical agents may be analgesic sparing in combination regimens [96]. Side effects include skin irritations, which are typically mild. Topical diclofenac has been reported to be effective in relieving pain caused by $\mathrm{OA}$ of the knee [97-99]. Topical 1\% diclofenac sodium gel was shown to be an effective analgesic in a study of 385 primary hand OA patients, with about $9 \%$ of diclofenac patients experiencing adverse events (compared to $4 \%$ in placebo group) and $5 \%$ of diclofenac patients discontinuing therapy because of adverse events (2\% in placebo group) [100]. In another study of 216 patients with OA of the knee treated with topical diclofenac to manage flares, diclofenac was effective in reducing pain but caused skin irritation in $39 \%$ of patients, with $5 \%$ choosing to discontinue therapy [101]. Topical NSAIDs do not appear to have gastrointestinal adverse effects typical of oral NSAIDs [102], but long-term studies are warranted to confirm this. OA treatment with topical lidocaine (5\% lidocaine medicated plaster) as monotherapy or add-on therapy resulted in significant improvements in pain intensity [103-105], physical function, and stiffness [103]. The use of topical capsaicin in OA is discussed controversially: topical capsaicin is recommended for hand OA but not for knee OA according to the ACR guidelines (American College of Rheumatology) [106], whereas according to a recent review "concerns exist that capsaicin-induced nerve desensitization is not fully reversible and that its autonomic nerve effects may increase the risk of skin ulcers in diabetic patients" [107]. 


\section{COMBINATION THERAPIES}

The multimechanistic nature of OA, RA and most other chronic pain indications suggests that a multimodal or combination approach to analgesia may be appropriate to manage pain. Combining two analgesic agents may allow for an additive or synergistic effect, which can affect both the drug's analgesic efficacy as well as its side effect profile $[108,109]$. Additive effects mean that the effects of both agents are combined. Synergistic effects result in a global effect that is greater than the sum of its parts. It is important to understand that additive and synergistic effects may imply side effects as well as efficacy. Furthermore, additive and synergistic effects may occur, yet fail to be clinically relevant. For these reasons, combination therapy holds promise in theory, but must be carefully evaluated and tested in actual clinical practice.

Fixed-dose combination analgesic products offer certain practical advantages, in that they are convenient, reduce the pill burden, and may allow for lower dosages that might be insufficient if the compounds were taken individually. Fixeddose combination analgesics should have complementary mechanisms of action and evidence supporting their safety and effectiveness. A drawback to fixed-dose combination analgesic products is inflexibility, in that the doses may not be ideal for the particular patient, and the fact that for continuous pain relief, generally a medication intake several times a day is required.

Paracetamol is often a component of combination products. A potential concern for such products is that they may obscure the patient's cumulative dose of paracetamol (which should not exceed $4 \mathrm{~g}$ in healthy adults [110]). Typical combination products with paracetamol include opioid combinations (codeine, tramadol, oxycodone, etc.). These products may be opioid sparing, because they provide effective analgesia at lower opioid doses than opioids taken in monotherapy [111]. Synergistic analgesic benefits have been demonstrated for the fixed dose combination tramadol/paracetamol [112, 113].

The Appendix lists all fixed-dose combination products with paracetamol that have been investigated for OA and RA pain treatment. They include paracetamol + strong opioids (oxycodone), + weak opioids (tramadol, codeine), and + NSAIDs (ibuprofen, etodolac, aceclofenac).

\section{PAIN CONTROL FOR OA AND RA PATIENTS}

Paracetamol is effective in treating certain types of OA. The drug is considered as first-line treatment for mild to moderate pain [114]. However, OA patients often prefer NSAIDS for better pain relief [115]. NSAIDs are targeted therapy for pain management in RA patients, but are not appropriate for long-term disease control [49, 116-118].

Fixed-dose combination products are seldom mentioned in available OA and RA guidelines [49, 50, 116-120]. The NICE guideline initially recommends paracetamol for all OA pain or topical NSAIDs for hand and knee OA ahead of oral NSAIDs, COX-2 inhibitors or opioids [50]. Topical capsaicin should be considered an adjunct to core treatment for hand and knee OA, and intra-articular corticosteroid injections an adjunct in all OA pain. The OARSI guideline recommends the initial administration of paracetamol for mild to moderate knee or hip OA, and topical NSAIDs and capsaicin as adjuncts or alternatives to oral analgesics in knee OA pain [119]. Weak opioids and narcotic analgesics can be considered for refractory pain but stronger opioids should only be used for severe pain in exceptional circumstances. The evidence presented included fixed-dose combinations of opioids and paracetamol. Both the NICE and OARSI guidelines recommend the use of oral NSAIDs at the lowest effective dose [50, 119]; long-term use should be avoided [119]. The recent ACR recommendations list topical capsaicin, topical NSAIDs, oral NSAIDs (including COX-2 inhibitors) and tramadol for initial pain treatment of hand OA, and advise against intra-articular therapies and opioid analgesics [106]. They recommend a similar approach for knee and hip OA which includes paracetamol, oral NSAIDs, tramadol, and intra-articular corticosteroid injections. Topical NSAIDs are recommended in knee OA (in particular for patients $\geq 75$ years instead of oral NSAIDs) but there is no recommendation in hip OA. Topical capsaicin is not recommended in knee OA. Opioid analgesics are strongly recommended only in symptomatic knee or hip OA following insufficient response to both nonpharmacological and pharmacological treatments and where patients are not suitable for total joint arthroplasty.

Early use of DMARDs in RA patients is of high importance [121, 122] ; however, as pain is a major complaint in these patients, they commonly take analgesics from the very beginning. According to EULAR, symptomatic patients presenting with early arthritis should be treated with NSAIDs after careful evaluation of gastrointestinal, renal, and cardiovascular status [116]. The BSR guideline for long-term RA management recommends a stepped approach with NSAIDs co-prescribed with a proton pump inhibitor in the short term [117]. The NICE guideline suggests analgesics (for example paracetamol, codeine or compound analgesics [=fixed-dose combinations]) to potentially reduce the need for long-term NSAID or COX-2 inhibitor treatment [49].

\section{PANEL CONSIDERATIONS}

The panel reached several general and specific conclusions on pain management for arthritis patients. While patient safety must be paramount, clinicians must address chronic pain associated with OA and RA. Not treating pain is not an option. Pain guidelines must offer clinicians better recommendations by taking into account the impact of pain as well as the multiple mechanisms of RA and OA pain. It is particularly important that clinicians realize that arthritis pain is not limited to nociception, but rather that non-nociceptive, neuropathic, and central mechanisms are also important components of OA and RA pain.

NSAIDs and paracetamol are commonly used, often recommended, and effective agents for the management of pain. However, they are not without potential risks, especially in the elderly and patients with renal, 
gastrointestinal, or cardiovascular disease. High doses and long-duration use of NSAIDs to manage moderate to severe pain have been associated with tolerability issues and serious adverse events as well. Their role in the management of the chronic pain associated with OA and RA is thus limited. Higher doses of paracetamol have been associated with liver toxicity, and since paracetamol is a "hidden" ingredient in many over-the-counter products and other combination products, the hepatic injury is of particular concern. Fixeddose combination products including paracetamol may offer the drug and the combined agent in relatively low doses. Despite such lower-dose paracetamol treatment, patients should be educated in general about the dangers of paracetamol toxicity and cautioned about the amount of paracetamol contained in any combination products they may be prescribed.

Fixed-dose combinations of paracetamol provide a multimechanistic analgesic approach, which may be appropriate to address the pain of OA and RA. Fixed-dose weak opioid/paracetamol combination products have been shown to be effective in managing various types of moderate to severe pain, including the pain of OA and RA, with good tolerability. Tramadol, because of its opioid and nonopioid mechanisms of action, appears to be a promising opioid component in combinations for treating OA and RA pain.

Arthritis-related pain is generally characterized by flares of pain and periods of remission or relatively diminished pain. To manage long-term arthritis pain, a low-dose fixeddose combination product should be considered as the primary analgesic, providing safe and acceptable multimechanistic pain relief. NSAIDs should only be used to manage acute flares associated with inflammation. This is the reverse of a common treatment regimen in which patients take chronic NSAID therapy and use opioids to manage pain from flares. Potential advantages of using a low-dose opioid combination product include a broader analgesic spectrum, complementary pharmacokinetic profile, potentially synergistic analgesic benefits, and improved ratio of efficacy to adverse effects.

\section{CONCLUSION}

Despite the wealth of analgesic options, treating arthritisrelated pain is still a challenge for clinicians balancing efficacy with safety aspects. Growing understanding of the multiple mechanisms of arthritis pain has given clinicians greater appreciation for a multimechanistic approach. The use of combination products, such as tramadol and paracetamol for long-term pain management, is a good option with proven evidence for relieving pain. NSAIDs are effective pain relievers and helpful as add-on treatment for the painful flares of arthritis. They are not safe at high doses or for long-term use, especially in the frail and elderly. Revised guidelines are required to help clinicians to better understand safe, effective treatment options for arthritisrelated pain.

\section{LIST OF PANEL PARTICIPANTS}

Participants in the conference were: Mart van de Laar* (Arthritis Center Twente, Enschede, Netherlands); Joseph
Pergolizzi* (Johns Hopkins University, Baltimore, Maryland, USA and the Association of Chronic Pain Patients, Houston, Texas, USA); Richard Langford (Anaesthetics Laboratory, St. Bartholomew's Hospital, London, UK); Hans-Ulrich Mellinghoff* (Department of Endocrinology, Diabetology and Osteology, Kantonsspital St. Gallen, Switzerland); Ignacio Morón Merchante* (Centro de Salud Universitario Goya, Madrid, Spain); Srinivas Nalamachu* (Kansas University Medical Center, Kansas City, Missouri and International Clinic Research, Leawood, Kansas, USA); Joanne O'Brien* (Beaumont Hospital, Dublin, Ireland); Serge Perrot* (Internal Medicine and Therapeutics Department, Hôtel Dieu Hospital, Paris Descartes University, France); Robert B. Raffa* (Department of Pharmaceutical Sciences, Temple University School of Pharmacy, Philadelphia, USA); Birgit Brett (Brett Medical Writing, Pulheim, Germany); Karla Schwenke (Medical Affairs, Grünenthal GmbH, Aachen Germany); and Detlef von Zabern (Medical Affairs, Grünenthal GmbH, Aachen, Germany). Authors are indicated with an asterisk.

\section{CONFLICT OF INTEREST}

ML received consultancy honoraria from Merck the Netherland, Pfizer Europa and Grünenthal $\mathrm{GmbH}$ and speaker honoraria from Pfizer Europa. JVP received consultancy honoraria from Grünenthal $\mathrm{GmbH}$, Baxter, Endo Pharmaceuticals, and Hospira. HUM received consultancy honoraria from Grünenthal $\mathrm{GmbH}$. IMM received consultancy honoraria from Boehringer Ingelheim, Grünenthal GmbH, Merck Sharp \& Dohme Corporation, and Takeda Pharmaceuticals Europe and has received lecture fees from Almirall, Astra-Zeneca, Boehringer Ingelheim, Bristol Myers Squibb, Esteve, Grünenthal GmbH, Eli Lilly and Company, Merck Sharp \& Dohme Corporation, Novartis, and Sanofi-Avenits. SN has received consultancy honoraria or research grants from the following companies in the past five years: Grünenthal $\mathrm{GmbH}$, Johnson and Johnson, Endo Pharmaceuticals, Cephalon, Alphapharma, King Pharmaceuticals, Allergan, ProStakan, and Covidien. JOB received consultancy honoraria from Grünenthal $\mathrm{GmbH}$. SP received consultancy honoraria from Grünenthal GmbH. $\mathrm{RBR}$ is a speaker, consultant, and/or basic science investigator for several pharmaceutical companies involved in analgesic research, but receives no royalty (cash or otherwise) from the sale of any product; he received consultancy honoraria from Grünenthal $\mathrm{GmbH}$.

\section{ACKNOWLEDGEMENTS}

The meeting was supported by Grünenthal $\mathrm{GmbH}$, Aachen, Germany. The authors were compensated for their participation in the initial consensus meeting but did not receive honoraria for the finally agreed consensus statement and their work on the manuscript. The authors acknowledge editorial assistance from Jo Ann LeQuang (LeQ Medical, Texas, USA), Elke Grosselindemann (Brett Medical Writing, Bibra Lake, Australia) and Birgit Brett (Brett Medical Writing, Pulheim, Germany). All costs associated with the publication of the manuscript were met by Grünenthal $\mathrm{GmbH}$, Aachen, Germany. 


\section{APPENDIX}

Fixed-Dose Combination Therapies for Osteoarthritis and Rheumatoid Arthritis Pain. Only Combinations of Paracetamol with Other Analgesic Agents were Included. The List of Studies was Obtained Through PubMed Searches and Reference Lists of Pain Review Articles

\begin{tabular}{|c|c|c|c|c|c|}
\hline \multicolumn{6}{|c|}{ Strong Opioid/APAP Combinations } \\
\hline Corsinovi 2009 [124] & $\begin{array}{l}154 \text { women nursing } \\
\text { home residents with } \\
\text { moderate to severe } \\
\text { OA pain }\end{array}$ & $\begin{array}{l}\text { Oxycodone/APAP } \\
\text { (average dose 16/900 } \\
\text { mg) and codeine/APAP } \\
\text { (average dose 115/1916 } \\
\mathrm{mg} \text { ) }\end{array}$ & $\begin{array}{l}\text { Conventional } \\
\text { therapy (NSAIDs, } \\
\text { APAP, COX-2 } \\
\text { inhibitors) }\end{array}$ & $\begin{array}{l}\text { Oxycodone/APAP and } \\
\text { codeine/APAP } \\
\text { significantly reduced } \\
\text { mean pain at six weeks } \\
\text { versus conventional } \\
\text { therapy ( }<0.001 \text { and } \\
\mathrm{p}=0.004, \text { respectively) }\end{array}$ & $\begin{array}{l}\text { AEs did not differ } \\
\text { significantly among groups. } \\
\text { Patients were all elderly } \\
\text { females. }\end{array}$ \\
\hline Palangio $2000[126]$ & $\begin{array}{l}469 \text { chronic pain } \\
\text { patients }(31 \% \text { had } \\
\text { arthritis, } n=145)\end{array}$ & $\begin{array}{l}1 \text { tablet of } \\
\text { hydrocodone/ibuprofen } \\
7.5 / 200 \mathrm{mg} \text { daily (HI-1) } \\
\text { or } 2 \text { tablets of same (HI- } \\
\text { 2) }\end{array}$ & $\begin{array}{l}\text { Codeine/APAP } \\
30 / 300 \mathrm{mg}\end{array}$ & $\begin{array}{l}\text { HI-2 offered } \\
\text { significantly greater } \\
\text { pain relief than HI-1 or } \\
\text { comparator; no } \\
\text { efficacy differences } \\
\text { between HI-1 and } \\
\text { comparator }\end{array}$ & $\begin{array}{l}\text { No significant difference in } \\
\text { AEs by group ( } 83 \% \text { HI- } 2 \text {, } \\
80 \% \text { HI- } 1 \text {, and } 81 \% \\
\text { Comparator) but significantly } \\
\text { more HI- } 2 \text { patients } \\
\text { discontinued therapy due to } \\
\text { adverse events compared to } \\
\text { HI- }(26 \% \text { vs } 15 \%, \mathrm{p}=0.013)\end{array}$ \\
\hline Conaghan 2011 [127] & $\begin{array}{l}220 \text { patients with hip } \\
\text { and/or knee pain } \\
\geq 60 \text { years of age }\end{array}$ & $\begin{array}{l}\text { 7-day buprenorphine } \\
\text { patches (range 5-25 } \\
\mu \mathrm{g} / \mathrm{h} \text { ) + APAP } 1000 \mathrm{mg} \\
\text { qid }\end{array}$ & $\begin{array}{l}\text { Codeine/APAP } \\
\text { range } 16 \mathrm{mg} / 1000 \\
\mathrm{mg} \text { qid to } 60 \\
\mathrm{mg} / 1000 \mathrm{mg} \text { qid }\end{array}$ & $\begin{array}{l}\text { Non-inferiority of } \\
\text { patch+APAP to } \\
\text { codeine/APAP } \\
\text { combination regarding } \\
\text { analgesic efficacy } \\
\text { Comparable incidence } \\
\text { of AEs }\end{array}$ & $\begin{array}{l}\text { High withdrawal rates in } \\
\text { both groups }\end{array}$ \\
\hline Park 2011 [129] & $\begin{array}{l}97 \text { knee OA patients } \\
\text { in sub-study (part of } \\
\text { larger study, } n=112 \text { ) }\end{array}$ & $\begin{array}{l}\text { Tramadol/APAP } \\
\text { (37.5/325 mg) Mean } \\
\text { dose } 3.23 \text { tablets/day }\end{array}$ & NSAID & $\begin{array}{l}\text { No significant } \\
\text { differences in } \\
\text { analgesia or AEs }\end{array}$ & \\
\hline Alwine 2000 [130] & $\begin{array}{l}403 \text { patients with } \mathrm{OA} \\
\text { or low back pain }\end{array}$ & $\begin{array}{l}\text { Tramadol/APAP ( } 37.5 \\
\mathrm{mg} / 325 \mathrm{mg}) 1 \text { to } 3 \\
\text { tablets per day }\end{array}$ & $\begin{array}{l}\text { 4-week active } \\
\text { control, thereafter } \\
\text { open label }(24 \mathrm{~m})\end{array}$ & $\begin{array}{l}\text { Tramadol/APAP rated } \\
\text { "excellent" or "very } \\
\text { good" by } 39 \% \text { of } \\
\text { patients and } 40 \% \text { of } \\
\text { investigators, average } \\
\text { daily dose was } 157 \\
\text { mg/1363 mg. }\end{array}$ & $\begin{array}{l}24 \% \text { of patients discontinued } \\
\text { due to AEs }\end{array}$ \\
\hline
\end{tabular}


(APPENDIX) contd......

\begin{tabular}{|c|c|c|c|c|c|}
\hline Study & $\mathbf{N}$ & Agent(s) & Comparator & Results & Comments \\
\hline Rosenthal 2004 [131] & $\begin{array}{l}\text { Subset of } 113 \text { patients } \\
\geq 65 \text { years with } \\
\text { painful OA flares } \\
\text { (from larger study of } \\
308 \text { patients) on } \\
\text { stable NSAID or } \\
\text { COX-2 inhibitor } \\
\text { therapy } \geq 3 \text { months }\end{array}$ & $\begin{array}{l}\text { Tramadol/APAP } \\
(37.5 / 325 \mathrm{mg} \text { ) as add on } \\
\text { (mean daily dose } \\
168 / 1.458 \mathrm{mg} \text { ) }\end{array}$ & $\begin{array}{l}\text { Control continued } \\
\text { NSAID or COX-2 } \\
\text { inhibitor therapy }\end{array}$ & $\begin{array}{l}\text { Tramadol/APAP } \\
\text { patients had } \\
\text { significantly reduced } \\
\text { daily pain intensity and } \\
\text { significantly greater } \\
\text { average daily pain } \\
\text { relief }\end{array}$ & $\begin{array}{l}23 \% \text { of tramadol/APAP and } \\
9 \% \text { of control patients } \\
\text { reported treatment-related } \\
\text { AEs. Tramadol/APAP } v s \\
\text { control rates of constipation } \\
\text { and somnolence were } 4.3 \% \\
v s 2.3 \% \text { and } 2.9 \% \text { vs } 2.3 \% \text {, } \\
\text { respectively. }\end{array}$ \\
\hline Silverfield 2002 [132] & $\begin{array}{l}308 \text { OA patients with } \\
\text { flare on stable } \\
\text { NSAID or COX-2 } \\
\text { inhibitor therapy }\end{array}$ & $\begin{array}{l}\text { Tramadol/APAP } \\
(37.5 / 325 \mathrm{mg}) \text { as add on }\end{array}$ & $\begin{array}{l}\text { Control continued } \\
\text { NSAID or COX-2 } \\
\text { inhibitor therapy }\end{array}$ & $\begin{array}{l}\text { Tramadol/APAP } \\
\text { patients had } \\
\text { significantly reduced } \\
\text { daily pain intensity and } \\
\text { significantly greater } \\
\text { average daily pain } \\
\text { relief }\end{array}$ & $\begin{array}{l}\text { AEs occurred in } 24 \% \text { of } \\
\text { tramadol/APAP and } 8 \% \text { of } \\
\text { control group; } 13 \% \text { of } \\
\text { tramadol/APAP and } 5 \% \text { of } \\
\text { control patients discontinued } \\
\text { for AEs }\end{array}$ \\
\hline Lee 2006 [133] & $\begin{array}{l}277 \text { RA patients on } \\
\text { stable NSAID and/or } \\
\text { DMARD therapy for } \\
\geq 1 \text { month }\end{array}$ & $\begin{array}{l}\text { Tramadol/APAP } \\
(37.5 / 325 \mathrm{mg}) \text { as add on }\end{array}$ & $\begin{array}{l}\text { Control continued } \\
\text { NSAID and/or } \\
\text { DMARD therapy }\end{array}$ & $\begin{array}{l}\text { Tramadol/APAP } \\
\text { patients had } \\
\text { significantly greater } \\
\text { pain relief and lower } \\
\text { daily pain intensity }\end{array}$ & $\begin{array}{l}\text { AEs were } 57.6 \% \text { in } \\
\text { tramadol/APAP group } v s \\
22.4 \% \text { in control }(\mathrm{p}<0.001)\end{array}$ \\
\hline Choi 2007 [111] & $\begin{array}{l}250 \text { patients with pain } \\
\text { from knee OA on } \\
\text { stable NSAID therapy }\end{array}$ & $\begin{array}{l}\text { Tramadol/APAP } \\
(37.5 / 325 \mathrm{mg}) \\
\text { Mean daily dose } \\
112.5 / 1.975 \mathrm{mg}\end{array}$ & $\begin{array}{l}\text { Patients were } \\
\text { randomized to } \\
\text { titration and non- } \\
\text { titration groups }\end{array}$ & $\begin{array}{l}\text { Tramadol/APAP } \\
\text { reduced pain in both } \\
\text { titration and } \\
\text { nontitration groups }\end{array}$ & $\begin{array}{l}\text { This was a safety study; } \\
\text { discontinuation rate was } \\
\text { significantly lower in titration } \\
\text { group with nausea, vomiting } \\
\text { and dizziness the most } \\
\text { common AEs (all } \\
\text { significantly more frequent in } \\
\text { the nontitration group). }\end{array}$ \\
\hline \multicolumn{6}{|c|}{ NSAID/APAP Combinations } \\
\hline Doherty 2011 [134] & $\begin{array}{l}892 \text { patients with } \\
\text { chronic knee pain } \\
\text { ( } 85 \% \text { had OA) }\end{array}$ & $\begin{array}{l}\text { Two active arms: } 1 \\
\text { tablet or } 2 \text { tablets daily } \\
\text { of ibuprofen/APAP } \\
200 / 500 \mathrm{mg}\end{array}$ & $\begin{array}{l}\text { Two comparative } \\
\text { arms: Ibuprofen } 400 \\
\text { mg or paracetamol } \\
1000 \mathrm{mg}\end{array}$ & $\begin{array}{l}\text { At day } 10,2 \\
\text { combination tablets } \\
\text { were significantly } \\
\text { better than APAP } \\
\text { monotherapy; at } 13 \\
\text { weeks, significantly } \\
\text { more patients found } \\
\text { combination therapy (1 } \\
\text { or } 2 \text { tablets) excellent } \\
\text { or good versus APAP } \\
\text { monotherapy }\end{array}$ & $\begin{array}{l}\text { Decreases in hemoglobin }(\geq \\
1 \mathrm{~g} / \mathrm{dl} \text { ) occurred in all groups } \\
\text { but was twice as frequent in } \\
\text { patients taking } 2 \text { combination } \\
\text { tablets daily compared to } \\
\text { monotherapy }\end{array}$ \\
\hline Pareek 2010 [135] & $\begin{array}{l}220 \text { patients with } \\
\text { knee OA flare }\end{array}$ & $\begin{array}{l}\text { Etodolac } 300 \mathrm{mg} / \mathrm{APAP} \\
500 \mathrm{mg} \text { BID }\end{array}$ & $\begin{array}{l}\text { Etodolac } 300 \mathrm{mg} \\
\text { BID }\end{array}$ & $\begin{array}{l}\text { Etodolac/APAP } \\
\text { significantly reduced } \\
\text { pain intensity } \\
(\mathrm{p}<0.001) \text { and } \\
\text { improved function }\end{array}$ & $\begin{array}{l}\text { Results noticeable within } 30 \\
\text { minutes of first dose; AEs } \\
\text { similar in both groups }\end{array}$ \\
\hline Pareek 2009 [136] & $\begin{array}{l}199 \text { patients with OA } \\
\text { flares }\end{array}$ & $\begin{array}{l}\text { Aceclofenac } 100 \\
\text { mg/APAP } 500 \mathrm{mg} \text { BID }\end{array}$ & $\begin{array}{l}\text { Aceclofenac } 100 \mathrm{mg} \\
\text { BID }\end{array}$ & $\begin{array}{l}\text { Aceclofenac/APAP } \\
\text { was superior to } \\
\text { monotherapy in pain } \\
\text { intensity differences, } \\
\text { sum of pain intensity } \\
\text { differences, and } \\
\text { patients'/ investigators' } \\
\text { assessments }\end{array}$ & $\begin{array}{l}\text { Combination had more rapid } \\
\text { onset of action; AEs similar } \\
\text { in both groups (about 10\%) }\end{array}$ \\
\hline
\end{tabular}

$\mathrm{AE}=$ adverse event, $\mathrm{APAP}=$ paracetamol, $\mathrm{LBP}=$ low back pain, $\mathrm{NS}=$ =not significant, $\mathrm{OA}=0$ steoarthritis, $\mathrm{VAS}=$ =visual analogue scale (pain measurement).

\section{REFERENCES}

[1] Arendt-Nielsen L, Nie H, Laursen M, et al. Sensitization in patients with painful knee osteoarthritis. Pain 2010; 149: 573-81.

[2] Woolf CJ. Central sensitization: implications for the diagnosis and treatment of pain. Pain 2011; 152(3 Suppl): S2-15.

[3] Dray A. New horizons in pharmacologic treatment for rheumatic disease pain. Rheum Dis Clin N Am 2008; 34: 481-505.

[4] Peppin J. The marginalization of chronic pain patients on chronic opioid therapy. Pain Phys 2009; 12: 493-8.
[5] Andersson HI. Increased mortality among individuals with chronic widespread pain relates to lifestyle factors: a prospective populationbased study. Disabil Rehabil 2009; 31(24): 1980-7.

[6] Torrance N, Elliott AM, Lee AJ, Smith BH. Severe chronic pain is associated with increased 10 year mortality. A cohort record linkage study. Eur J Pain 2010; 14(4): 380-6.

[7] Andersson HI. The course of non-malignant chronic pain: a 12-year follow-up of a cohort from the general population. Eur J Pain 2004; $8(1): 47-53$.

[8] Brennan F, Carr D, Cousins M. Pain management: a fundamental human right. Anesth Analg 2007; 105: 205-21. 
[9] Fishman S. Recognizing pain management as a human right: a first step. Int Anesth Res Soc 2007; 105(1): 8-9.

[10] Macpherson C. Undertreating pain violates ethical principles. J Med Ethics 2010; 35: 603-6.

[11] Goldring M, Goldring S. Osteoarthritis. J Cell Physiol 2007; 213: 626-34.

[12] Baker K, Grainger A, Niu J, et al. Relation of synovitis to knee pain using contrast-enhanced MRIs. Ann Rheum Dis 2010; 69(10): 177983.

[13] Bonnet C, Walsh D. Osteoarthritis, angiogenesis and inflammation. Rheumatology 2005; 44: 7-16.

[14] Ashraf S, Wibberley H, Mapp P, Hill R, Wilson D, Walsh D. Increased vascular penetration and nerve growth in the meniscus: a potential source of pain in osteoarthritis. Ann Rheum Dis 2011; 70: 523-9.

[15] Mease P, Hanna S, Frakes E, Altman R. Pain mechanisms in osteoarthritis: understanding the role of central pain and current approaches to its treatment. J Rheumatol 2011; 38: 1546-51.

[16] Mandl L. Treating the pain of osteoarthritis-where do we go from here? J Rheumatol 2011; 38(8): 1535-7.

[17] Farrell M, Gibson S, McMeeken J, Helme R. Pain and hyperalgesia in osteoarthritis of the hands. J Rheumatol 2000; 27: 441-7.

[18] Kosek E, Orderberg G. Lack of pressure pain modulation by heterotopic noxious conditioning stimulation in patients with painful osteoarthritis before, but not following, surgical pain relief. Pain 2000; 88(1): 69-78.

[19] O'Driscoll S, Jayson M. Pain threshold analysis in patients with osteoarthritis of the hip. BMJ 1974; 3: 714-5.

[20] Lee Y, Nassikas N, Clauw D. The role of the central nervous system in the generation and maintenance of chronic pain in rheumatoid arthritis, osteoarthritis and fibromyalgia. Arth Res Ther 2011; 13: 211-21.

[21] Sofat N, Ejindu V, Kiely P. What makes osteoarthritis painful? The evidence for local and central pain processing. Rheumalogy 2011; 50: 2157-65

[22] Seed S, Dunican K, Lynch A. Osteoarthritis: a review of treatment options. Geriatrics 2009; 64(10): 20-9.

[23] American Geriatric Society Panel on the Pharmacological Management of Persistent Pain in Older Persons. Pharmacological Management of Persistent Pain in Older Persons. J Am Ger Soc 2009; 57(8): 1331-46.

[24] Pergolizzi J, Böger R, Budd K, et al. Opioids and the management of chronic severe pain in the elderly: consensus statement of an international expert panel with focus on the six clinically most often used World Health Organization step III opioids (buprenorphine, fentanyl, hydromorphone, methadone, morphine, oxycodone). Pain Pract 2008; 4: 287-313.

[25] Cheng H-Y, Penninger J. DREAMing about arthritic pain. Ann Rheum Dis 2004; 63(Suppl II): ii72-5.

[26] Huskisson E, Hart F. Pain threshold and arthiritis. BMJ 1972; 4: 1935.

[27] Konttinen Y, Honkanen V, Gronblad M, Keinonen M, Santavirta N, Santavirta S. The relation of extraarticular tenderness to inflammatory joint disease and personality in patients with rheumatoid arthritis. J Rheumatol 1992; 19: 851-5.

[28] Wendler J, Hummel T, Reissinger M, et al. Patients with rheumatoid arthritis adapt differently to repetitive painful stimuli compared to healthy controls. J Clin Neurosci 2001; 8(3): 272-7.

[29] Perrot S. Should we switch from analgesics to the concept of "pain modifying analgesic drugs (PMADS)" in osteoarthritis and rheumatic chronic pain conditions? Pain 2009; 146: 229-30.

[30] Kroenke K, Krebs E, Blair M. Pharmacotherapy of chronic pain: a synthesis of recommendations from systematic reviews. Gen Hos Psych 2009; 31: 206-19.

[31] Vonkeman H, Fernandes R, van de Laar M. Under-utilization of gastroprotective drugs in patients with NSAID-related ulcers. Int J Clin Pharmacol Ther 2007; 45(5): 281-8.

[32] Bhatt D, Scheiman J, Abraham N, et al. ACCF/ACG/AHA 2008 expert consensus document on reducing the gastrointestinal risks of antiplatelet therapy and NSAID use: a report of the American College of Cardiology Foundation Task Force on Clinical Expert Consensus Documents. J Am Coll Cardiol 2008; 52(18): 1502-17.

[33] McNeil-NSAID Washington, D.C.: Food and Drug Adminstration; 2002 [cited 2012 September 9]; Available from: http://www.fda.gov/ ohrms/dockets/ac/02/briefing/3882B2_02_McNeil-NSAID.htm
[34] Antman E, Bennett J, Daugherty A, Furberg C, Roberts H, Taubert $\mathrm{K}$. Use of nonsteroidal antiinflammatory drugs: an update for clinicians: a scientific statement from the American Heart Association. Circulation 2007; 115(12): 1634-42.

[35] Hippisley-Cox J, Coupland C. Risk of myocardial infarction in patients taking cylco-oxygenase- 2 inhibitors or conventional nonsteroidal anti-inflammatory drugs: population based nested casecontrol analysis. BMJ 2005; 330: 1366.

[36] Laine L, White W, Rostom A, Hochberg M. COX-2 selective inhibitors in the treatment of osteoarthritis. Semin Arthritis Rheum 2008; 38: 165-87.

[37] Trelle S, Reichenbach S, Wandel S, et al. Cardiovascular safety of non-steroidal anti-inflammatory drugs: network meta-analysis. BMJ 2011; 342: c7086.

[38] Friedewald V, Bennett J, Christo J, et al. AJC Editor's consensus: Selective and nonselective nonsteroidal anti-inflammatory drugs and cardiovascular risk. Am J Cardiol 2010; 106(6): 873-84.

[39] Gaziano J. Nonnarcotic analgesics and hypertension. Am J Cardiol 2006; 97(Suppl): 10E-6E.

[40] Kearney P, Baigent C, Godwin J, Halls H, Emberson J, Patrono C. Do selective cyclo-oxygenase-2 inhibitors and traditional nonsteroidal anti-inflammatory drugs increase the risk of atherothrombosis? Meta-analysis of randomised trials. BMJ 2006; 332(7553): 1302-8.

[41] Hunt R, Lanas A, Stichtenoth D, Scarpignato C. Myths and facts in the use of anti-inflammatory drugs. Ann Med 2009; 41: 423-37.

[42] Chan F, Lanas A, Scheiman J, Berger M, Nguyen H, Goldstein J. Celecoxib versus omeprazole and diclofenac in patients with osteoarthritis and rheumatoid arthritis (CONDOR): a randomised trial. Lancet 2010; 376: 173-9.

[43] Ofman J, MacLean C, Straus W, et al. A metaanalysis of severe upper gastrointestinal complications of nonsteroidal antiinflammatory drugs. J Rheumatol 2002; 29(4): 804-12.

[44] Boers M, Tangelder M, van Ingen H, Fort J, Goldstein J. The rate of NSAID-induced endoscopic ulcers increases linearly but not exponentially with age: a pooled analysis of 12 randomised trials. Ann Rheum Dis 2007; 66(3): 417-8.

[45] Diclofenac sodium 50mg tablets. Surrey, England: Electronic medicines compendium; 2005 [updated December 2008; cited 2012 September 9]; Available from: http://www.medicines.org.uk/emc /medicine/22653\#INCOMPATIBILITIES

[46] Anadin ibuprofen 200mg tablets. Surrey, England: Electronic Medicines Compendium; 2011 [updated March 31, 2011; cited 2012 September 9]; Available from: http://www.medicines.org.uk/EMC/ medicine/15681/SPC/Anadin+Ibuprofen+200mg+Tablets/

[47] Naproxen 250mg tablets. Surrey, England: Electronic Medicines Compendium; 2011 [updated April 18, 2012; cited 2012 September 9]; Available from: http://www.medicines.org.uk/emc/medicine /23037/SPC\#INCOMPATIBILITIES

[48] Celebrex 100mg \& 200mg capsules. Surrey, England: Electronic Medicines Compendium; 2011 [updated May 3, 2011; cited 2012 September 9]; Available from: http://www.medicines.org.uk/emc/ medicine/14534\#INCOMPATIBILITIES

[49] NICE. Rheumatoid arthritis: the management of rheumatoid arthritis in adults. London: NICE; 2009 [cited 2010 December 18]; Available from: http://www.nice.org.uk/nicemedia/live/12131/43327/43327.pdf

[50] NICE. Osteoarthritis: the care and management of osteoarthritis in adults. London: National Institute for Health and Clinical Excellence; 2008; Available from: http://www.nice.org.uk/ nicemedia/pdf/CG59 NICEguideline.pdf [cited 2011 May 13]

[51] Hochberg M, Dougados M. Pharmacological therapy of osteoarthritis. Best Pract Res Clin Rheumatol 2001; 15(4): 583-93.

[52] Watkins P, Kaplowitz N, Slattery J, et al. Aminotransferase elevations in healthy adults receiving 4 grams of acetaminophen daily: a randomized controlled trial. JAMA 2006; 296(1): 87-93.

[53] Albertson T, Walker V, Stebbins M, Ashton E, Owen K, Sutter M. A population study of the frequency of high-dose acetaminophen prescribing and dispensing. Ann Pharmacother 2010; 44: 1191-5.

[54] Hornsby L, Whitley H, Hester E, Thompson M, Donaldson A. Survey of patient knowledge related to acetaminophen recognition, dosing, and toxicity. J Am Pharm Assoc 2010; 50(4): 485-9.

[55] Sudano I, Flammer A, Périat D, et al. Acetaminophen increases blood pressure in patients with coronary artery disease. Circulation 2010; 122(18): 1789-96.

[56] Forman J, Rimm E, Curhan G. Frequency of analgesic use and risk of hypertension among men. Arch Intern Med 2007; 167(4): 394-9. 
[57] Brandt K, Mazzuca S, Buckwalter K. Acetaminophen, like conventional NSAIDs, may reduce synovitis in osteoarthritic knees. Rheumatology 2006; 45: 1389-94.

[58] Flood J. The role of acetaminophen in the treatment of osteoarthritis. Am J Manag Care 2010; 16: S48-S54.

[59] WHO. WHO's pain ladder. Geneva, Switzerland: World Health Organization; 1986 [updated 2011; cited 2012 June 15]; Available from: http://www.who.int/cancer/palliative/painladder/en/.

[60] Raffa R, Friederichs E. The basic science aspect of tramadol hydrochloride. Pain Rev 1996; 3: 249-71.

[61] Cepeda M, Camargo F, Zea C, Valencia L. Tramadol for osteoarthritis. Cochrane Datab Syst Rev 2006; (3): CD005522.

[62] Rosenberg M. The role of tramadol ER in the treatment of chronic pain. Int J Clin Pract 2009; 63(10): 1531-43.

[63] Adams E, Breiner S, Cicero T, et al. A comparison of the abuse liability of tramadol, NSAIDs, and hydrocodone in patients with chronic pain. J Pain Symptom Manage 2006; 31(5): 465-76.

[64] Tramadol hydrochloride 50mg capsules. Surrey, England: Datapharm Communications Ltd; 2011 [updated 2 February 2011; cited 2011 December 15]; Available from: http://www.medicines.org.uk/emc/ medicine/24186/SPC/tramadol\%20hydrochloride $\% 2050 \mathrm{mg} \% 20$ caps ules/.

[65] Trescot A, Helm S, Hansen H, et al. Opioids in the management of chronic non-cancer pain: an update of American Society of the Interventional Pain Physicians' (ASIPP) Guidelines. Pain Phys 2008; 11: S5-S62.

[66] Birnbaum H, White A, Schiller M, Waldman T, Cleveland J, Roland C. Societal costs of prescription opioid abuse, dependence, and misuse in the United States. Pain Med 2011; 12(4): 657-67.

[67] Joranson D, Gilson A. Wanted: a public health approach to prescription opioid abuse and diversion. Pharmacoepidemiol Drug Saf 2006; 15: 632-4.

[68] Ling W, Mooney L, Hillhouse M. Prescription opioid abuse, pain and addiction: clinical issues and implications. Drug Alcohol Rev 2011; 30: 300-5.

[69] Minozzi S, Amato L, Davoli M. Development of dependence following treatment with opioid analgesics for pain relief: a systematic review. Addiction 2012; [Epub ahead of print].

[70] Schneider J, Matthews M, Jamison R. Abuse-deterrent and tamperresistant opioid formulations: what is their role in addressing prescription opioid abuse? CNS Drugs 2010; 24(10): 805-10.

[71] Raffa R, Pergolizzi J. Opioid formulations designed to resist/deter abuse. Drugs 2010; 70(13): 1657-75.

[72] Furlan A, Sandoval J, Mailis-Gagnon A, Tunks E. Opioids for chronic noncancer pain: a meta-analysis of effectiveness and side effects. CMAJ 2006; 174: 1589-94.

[73] Gianni W, Madaio A, Ceci M, et al. Transdermal buprenorphine for the treatment of chronic noncancer pain in the oldest old. J Pain Symptom Manage 2011; 41(4): 707-14.

[74] Vadivelu N, Hines R. Management of chronic pain in the elderly: focus on transdermal buprenorphine. Clin Interv Aging 2008; 3(3): 421-30.

[75] Afilalo M, Etropolski M, Kuperwasser B, et al. Efficacy and safety of tapentadol extended release compared with oxycodone controlled release for the management of moderate to severe chronic pain related to osteoarthritis of the knee: a randomized, double-blind, placebo- and active-controlled phase III study. Clin Drug Investig 2010; 30(8): 489-505.

[76] Wild J, Grond S, Kuperwasser B, et al. Long-term safety and tolerability of tapentadol extended release for the management of chronic low back pain or osteoarthritis pain. Pain Pract 2010; 10(5): 416-27.

[77] Lipman A. Treatment of chronic pain in osteoarthritis: do opioids have a clinical role? Curr Rheum Rep 2001; 3: 513-9.

[78] Pancrazio J, Kamatchi G, Roscoe A, Lynch Cr. Inhibition of neuronal $\mathrm{Na}+$ channels by antidepressant drugs. J Pharmacol Exp Ther 1998; 284(1): 208-14.

[79] Bechmann L, Best J, Haag S, Leineweber K, Gerken G, Holtmann G. Serotoninergic and non-serotoniergic effects of two tricyclic antidepressants on visceral nociception in a rat model. Scand $\mathbf{J}$ Gastroenterol 2009; 44(6): 680-6.

[80] Macfarlane J, Jalali S, Grace E. Trimipramine in rheumatoid arthritis: a randomized double-blind trial in relieving pain and joint tenderness. Curr Med Res Opin 1986; 10: 89-93.

[81] Sarzi Puttini P, Cazzola M, Boccassini L, et al. A comparison of dothiepin versus placebo in the treatment of pain in rheumatoid arthritis and the association of pain with depression. J Int Med Res 1988; 16: 331-7.

[82] Frank R, Kashani J, Parker J, et al. Antidepressant analgesia in rheumatoid arthritis. J Rheumatol 1988; 15: 1632-8.

[83] Ash G, Dickens C, Creed F, Jayson M, Tomenson B. The effects of dothiepin on subjects with rheumatoid arthritis and depression. Rheumatology 1999; 38: 959-67.

[84] Perrot S, Javier R-M, Marty M, LeJeunne C, Laroche F. Is there any evidence to support the use of anti-depressants in painful rheumatological conditions? Systematic review of pharmacological and clinical studies. Rheumatology 2008; 47: 1117-23.

[85] Dworkin R, O'Connor A, Audette J, et al. Recommendations for the pharmacological management of neuropathic pain: an overview and literature update. Mayo Clin Proc 2010; 85(3 Suppl): S3-S14.

[86] American Geriatrics Society 2012 Beers Criteria Update Expert Panel. American Geriatrics Society updated Beers criteria for potentially inappropriate medication use in older adults. J Am Geriatr Soc 2012; 60(4): 616-31.

[87] Uchitel OD, Di Guilmi MN, Urbano FJ, Gonzalez-Inchauspe C. Acute modulation of calcium currents and synaptic transmission by gabapentinoids. Channels 2010; 4(6): 490-6.

[88] Rahman W, Bauer C, Bannister K, Vonsy J, Dolphin A, Dickenson A. Descending serotonergic facilitation and the antinociceptive effects of pregabalin in a rat model of osteoarthritic pain. Mol Pain 2009; 7(5): 45.

[89] Moore R, Straube S, Wiffen P, Derry S, McQuay H. Pregabalin for acute and chronic pain in adults. Cochrane Datab Syst Rev 2009; 8(3): CD007076.

[90] Chappell A, Ossanna M, Liu-Seifert H, et al. Duloxetine, a centrally acting analgesic, in the treatment of patients with osteoarthritis knee pain: a 13-week, randomized, placebo-controlled trial. Pain 2009; 146: 253-60.

[91] Watanabe S, Bruera E. Corticosteroids as adjuvant analgesics. J Pain Symptom Manage 1994; 9: 442-5.

[92] den Uyl D, van Raalte DH, Nurmohamed MT, et al. Metabolic effects of high-dose prednisolone treatment in early rheumatoid arthritis: Balance between diabetogenic effects and inflammation reduction. Arthritis Rheum 2012; 64(3): 639-46.

[93] Grossman JM, Gordon R, Ranganath VK, et al. American College of Rheumatology 2010 recommendations for the prevention and treatment of glucocorticoid-induced osteoporosis. Arthritis Care Res 2010; 62(11): 1515-26.

[94] Franchimont D. Overview of the actions of glucocorticoids on the immune response: a good model to characterize new pathways of immunosuppression for new treatment strategies. Ann NY Acad Sci 2004; 1024: 124-37.

[95] National Health Service UK. Corticosteroids - side effects. Available from: http://www.nhs.uk/Conditions/Corticosteroid-\%28drugs \%29/P ages/Sideeffects.aspx [Cited 2012 September 12];

[96] Haynes S, Gemmell H. Topical treatments for osteoarthritis of the knee. Clin Chiroprac 2007; 10: 126-38.

[97] Bookman A, Williams K, Shainhouse J. Effect of a topical diclofenac solution for relieving symptoms of primary osteoarthritis of the knee: a randomized controlled trial. CMAJ 2004; 171(4): 333-8.

[98] Simon L, Grierson L, Naseer Z, Bookman A, Shainhouse J. Efficacy and safety of topical diclofenac containing dimethyl sulfoxide (DMSO) compared with those of topical placebo, DMSO vehicle and oral diclofenac for knee osteoarthritis. Pain 2009; 143: 238-45.

[99] Roth S, Shainhouse J. Efficacy and safety of a topical diclofenac solution (Pennsaid) in the treatment of primary osteoarthritis of the knee: a randomized, double-blind, vehicle-controlled clinical trial. Arch Intern Med 2004; 164: 2017-23.

[100] Altman R, Dreiser R-L, Fisher C, Chase W, Dreher D, Zacher J Diclofenac sodium gel in patients with primary hand osteoarthritis: a randomized, double-blind, placebo-controlled trial. J Rheumatol 2009; 36: 1991-9.

[101] Baer P, Thomas L, Shainhouse Z. Treatment of osteoarthritis of the knee with a topical diclofenac solution: a randomised controlled, 6week trial [ISRCTN53366886]. BMC Musculoskelet Disord 2005; 6: 44-53.

[102] Tugwell P, Wells G, Shainhouse J. Equivalence study of a topical diclofenac solution (pennsaid) compared with oral diclofenac in symptomatic treatment of osteoarthritis of the knee: a randomized controlled trial. J Rheumatol 2004; 31: 2002-12.

[103] Burch F, Codding C, Patel N, Sheldon E. Lidocaine patch 5\% improves pain, stiffness, and physical function in osteoarthritis pain 
patients. A prospective, multicenter, open-label effectiveness trial. Osteoarthritis Cartilage 2004; 12(3): 253-5.

[104] Galer B, Sheldon E, Patel N, Codding C, Burch F, Gammaitoni A. Topical lidocaine patch $5 \%$ may target a novel underlying pain mechanism in osteoarthritis. Curr Med Res Opin 2004; 20(9): 14558 .

[105] Gammaitoni A, Galer B, Onawola R, Jensen M, Argoff C. Lidocaine patch $5 \%$ and its positive impact on pain qualities in osteoarthritis: results of a pilot 2-week, open-label study using the Neuropathic Pain Scale. Curr Med Res Opin 2004; 20(Suppl 2): S13-S9.

[106] Hochberg MC, Altman RD, April KT, et al. American College of Rheumatology 2012 recommendations for the use of nonpharmacologic and pharmacologic therapies in osteoarthritis of the hand, hip, and knee. Arthritis Care Res (Hoboken) 2012; 64(4): 455-74.

[107] Altman RD, Barthel HR. Topical therapies for osteoarthritis. Drugs 2011; 71(10): 1259-79.

[108] Raffa R. Pharmacological aspects of successful long-term analgesia. Clin Rheumatol 2006; 25(Suppl 1): S9-S15.

[109] Raffa R, Clark-Vetri R, Tallarida R, Wertheimer A. Combination strategies for pain management. Expert Opin Pharmacother 2003; 4: 1697-708.

[110] Zhang W, Nuki G, Moskowitz RW, et al. OARSI recommendations for the management of hip and knee osteoarthritis: part III: changes in evidence following systematic cumulative update of research published through January 2009. Osteoarthritis Cartilage 2010; 18(4): 476-99.

[111] Choi C, Song J, Kang Y, et al. A 2-week, multicenter, randomized, double-blind, double-dummy, add-on study of the effects of titration on tolerability of tramadol/acetaminophen combination tablet in Korean adults with knee osteoarthritis pain. Clin Ther 2007; 29(7): $1381-9$.

[112] Raffa R, Friderichs E, Reimann W, Shank R, Codd E, Vaught J. Opioid and nonopioid components independently contribute to the mechanism of action of tramadol, an 'atypical' opioid analgesic. J Pharmacol Exp Ther 1992; 260(1): 275-85.

[113] Filitz J, Ihmsen H, Günther W, et al. Supra-additive effects of tramadol and acetaminophen in a human pain model. Pain Manage Nursing 2008; 136(3): 262-70.

[114] Magliano M, Morris V, Eds. Use of analgesics in rheumatology. London: Arthritis Research Campaign 2002.

[115] Wolfe F, Zhao S, Lane N. Preference for nonsteroidal antiinflammatory drugs over acetaminophen by rheumatic disease patients: a survey of 1,799 patients with osteoarthritis, rheumatoid arthritis, and fibromyalgia. Arthritis Rheum 2000; 43(2): 378-85.

[116] Combe B, Landewe R, Lukas C, et al. EULAR recommendations for the management of early arthritis: report of a task force of the European Standing Committee for International Clinical Studies Including Therapeutics (ESCISIT). Ann Rheum Dis 2007; 66(1): 3445 .

[117] Luqmani R, Hennell S, Estrach C, et al. British Society for Rheumatology and British Health Professionals in Rheumatology guideline for the management of rheumatoid arthritis (after the first 2 years). Rheumatology 2009; 48(4): 436-9.

[118] Ramiro S, Radner H, van der Heijde D, et al. Combination therapy for pain management in inflammatory arthritis (rheumatoid arthritis, ankylosing spondylitis, psoriatic arthritis, other spondyloarthritis). Cochrane Database Syst Rev 2011; (10): CD008886.

[119] Zhang W, Moskowitz R, Nuki G, et al. OARSI recommendations for the management of hip and knee osteoarthritis, Part II: OARSI evidence-based, expert consensus guidelines. Osteoarthritis Cartilage 2008; 16(2): 137-62.

[120] Luqmani R, Hennell S, Estrach C, et al. British Society for Rheumatology and British Health Professionals in Rheumatology guideline for the management of rheumatoid arthritis (the first two years). Rheumatology 2006; 45(9): 1167-9.
[121] Vermeer M, Kuper HH, Hoekstra M, et al. Implementation of a treatto-target strategy in very early rheumatoid arthritis: results of the Dutch Rheumatoid Arthritis Monitoring remission induction cohort study. Arthritis Rheum 2011; 63(10): 2865-72.

[122] Schipper LG, Vermeer M, Kuper HH, et al. A tight control treatment strategy aiming for remission in early rheumatoid arthritis is more effective than usual care treatment in daily clinical practice: a study of two cohorts in the Dutch Rheumatoid Arthritis Monitoring registry. Ann Rheum Dis 2012; 71(6): 845-50.

[123] Raffaeli W, Pari C, Corvetta A, et al. Oxycodone/acetaminophen at low dosage: an alternative pain treatment for patients with rheumatoid arthritis. J Opioid Manag 2010; 6(1): 40-6.

[124] Corsinovi L, Martinelli E, Fonte G, et al. Efficacy of oxycodone/acetaminophen and codeine/acetaminophen $v s$ conventional therapy in elderly women with persistent, moderate to severe osteoarthritis-related pain. Arch Gerontol Ger 2009; 49: 387-2.

[125] Mullican W, Lacy J. Tramadol/acetaminophen combination tablets and codeine/acetaminophen combination capsules for the management of chronic pain: a comparative trial. Clin Ther 2001; 23(9): 1429-45.

[126] Palangio M, Damask M, Morris E, et al. Combination hydrocodone and ibuprofen versus combination codeine and acetaminophen for the treatment of chronic pain. Clin Ther 2000; 22(7): 879-92.

[127] Conaghan P, O'Brien C, Wilson M, Schofield J. Transdermal buprenorphine plus oral paracetamol $v s$ an oral codeine-paracetamol combination for osteoarthritis of hip and/or knee: a randomised trial. Osteoarthritis Cartilage 2011; 19: 930-8.

[128] Emkey R, Rosenthal N, Wu S, Jordan D, Kamin M. Efficacy and safety of tramadol/acetaminophen tablets (Ultracet) as add-on therapy for osteoarthritis pain in subjects receiving a COX-2 nonsteroidal antiinflammatory drug: a multicenter, randomized, double-blind, placebo-controlled trial. J Rheumatol 2004; 31(1): 150-6.

[129] Park K-S, Choi J-J, Kim W-U, Min J-K, Park S-H, Cho C-S. The efficacy of tramadol/acetaminophen combination tablets (Ultracet ${ }^{\circledR}$ ) as add-on and maintenance therapy in knee osteoarthritis pain inadequately controlled by nonsteroidal anti-inflammatory drug (NSAID). Clin Rheumatol 2012; 31(2): 317-23.

[130] Alwine L. Long-term (2-year) analgesic efficacy of tramadol/ acetaminophen tablets. European League Against Rheumatism (EULAR) Congress 2000; Nice, France 2000. p. Poster 301.

[131] Rosenthal N, Silverfield J, Wu S, Jordan D, Kamin M. Tramadol/acetaminophen combination tablets for the treatment of pain associated with osteoarthritis flare in an elderly patient population. J Am Geriatr Soc 2004; 52(3): 374-80.

[132] Silverfield J, Kamin M, Wu S, Rosenthal N. Tramadol/ acetaminophen combination tablets for the treatment of osteoarthritis flare pain: a multicenter, outpatient, randomized, double-blind, placebo-controlled, parallel-group, add-on study. Clin Ther 2002; 24(2): 282-97.

[133] Lee E, Lee E, Park B, et al. Tramadol 37.5-mg/acetaminophen 325$\mathrm{mg}$ combination tablets added to regular therapy for rheumatoid arthritis pain: a 1-week, randomized, double-blind, placebocontrolled trial. Clin Ther 2006; 28(12): 2052-60.

[134] Doherty M, Hawkey C, Goulder M, et al. A randomised controlled trial of ibuprofen, paracetamol or a combination tablet of ibuprofen/paracetamol in community-derived people with knee pain. Ann Rheum Dis 2011; 70: 1534-41.

[135] Pareek A, Chandurkar N, Ambade R, Chandanwale A, Bartakke G. Efficacy and safety of etodolac-paracetamol fixed dose combination in patients with knee osteoarthritis flare-up: a randomized, doubleblind comparative evaluation. Clin J Pain 2010; 26: 561-6.

[136] Pareek A, Chandurkar N, Sharma V, Desai M, Kini S, Bartakke G. A randomized, multicentric, comparative evaluation of aceclofenacparacetamol combination with aceclofenac alone in Indian patients with osteoarthritis flare-up. Expert Opin Pharmacother 2009; 10(5): 727-35.

This is an open access article licensed under the terms of the Creative Commons Attribution Non-Commercial License (http://creativecommons.org/licenses/by-nc/ $3.0 /$ ) which permits unrestricted, non-commercial use, distribution and reproduction in any medium, provided the work is properly cited. 